\title{
TEMPORALITY IN A DISCUSSION OF SUSTAINABLE ARCHITECTURE
}

\author{
Bramasta Putra Redyantanu ${ }^{1^{*}}$, Rully Damayanti ${ }^{2^{*}}$ \\ ${ }^{1,2}$ Architecture Department, Petra Christian University \\ Jalan Siwalankerto No. 121-131, Surabaya 60235 - INDONESIA \\ *Corresponding author; Email: bramasta@petra.ac.id, rully@petra.ac.id
}

\begin{abstract}
Nowadays, sustainability has become one of the main aspects in architecture and urbanism. Limited land, space usage efficiency, public area occupancy by private sector and energy efficient are few examples of various factors that cause the temporality. Space temporality, instead of temporality in time and users, both planned and unplanned, becomes an interesting issue to be explored further. Literature studies and empirical observation are used in this article as reference to redefine the concept of 'space', in regards to its adaptability and flexibility in sustainable architecture. This research aims to construct a design guide of a temporal space (such as classifications, characters, and some other elements). There are several design guidelines that can help architect in designing an adaptable and flexible space or building. Space, user, and time (both adaptability and flexibility) are the key factors for a sustainable design.
\end{abstract}

Keywords: Sustainable architecture; temporality of space; temporality of time; temporality of user.

\section{INTRODUCTION}

Based on the recent global trend, the concept of sustainability has been integrated in every aspect of human life, including architecture. Energy, space usage, material sustainability, is some of the challenges that needed to be answered by architects through their design. Specifically, in architecture, space sustainability is reflected through their ability to adapt with various forms of condition, space, time and also user variety. Meanwhile, the space adaptability is highly influenced by the efficiency and effectiveness of a space function, both planned and unplanned.

Furthermore, in the discussion of a space function, one needs to pay attention to a 'temporality'. The issue of temporality is apparent in the cases such as street market, alun-alun, boarding house, and pavilion. One of the examples of a street market in Indonesia is the 'morning market', which is the most common case of temporary market in the country. In accordance to its naming, the morning market occurs only in the morning and it never lasts all day. Hence its location in various regular street that normally functions as circulation area. Another case is a boarding house, where it has time and user temporality issues that are crucial to be accommodated throughout the designing process.

This leads to the main argument on how temporality in space function is one of the answers to the sustainability challenge in architecture. Based on the field observation, in general, temporality issues in architecture are tightly related to these factors: space, user, and time. This study aims to identify the characteristics of an architectural temporality in its attempt to contribute to the discussion of a sustainable architectural design. In doing so, the goals of this paper is to provide a guideline to provoke a more adaptable and flexible space design from architect, which serves the base of a sustainable architecture.

\section{METHODOLOGY}

The research is based on a qualitative study that consists of two main stages. The first stage is a literature review that also serves as the basis of the theoretical model. This model employs one existing design of each of the three elements of temporality (space, user, and time). Based on this model, on the field observation, the researcher selects two architectural objects, located in Surabaya, for each of those three elements of temporality: temporality of space, temporality of time, and temporality of user. The second stage is the application of this model to several case studies. There are two categories of data for the case studies: 1) cases from secondary data (literature study on some of the existing internationally acknowledged architectural design; 2) cases from primary data (field observations done by authors).

\section{LITERATURE REVIEW}

In order to understand the context of the architectural space temporality, the theoretical model used on this research combines the conception of sociology of space by Lefebvre (1991), which then being developed further by Soja (1996), and the 
theory of sustainable architecture by Steerle (1997). Space is not simply defined as a planned or given physical boundaries. Space is a result of social construction on a physical form that occurs through a communication of meaning. Furthermore, it is the society who act as the user who determines and shapes this communication of meaning.

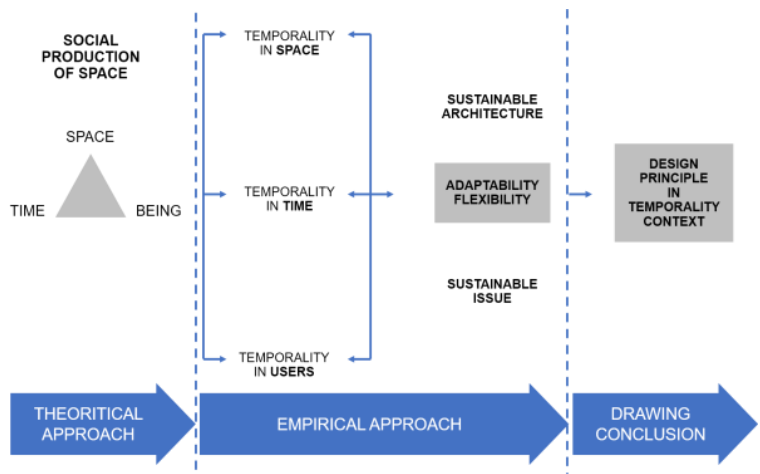

Fig. 1. Connection scheme of the temporality and sustainability study

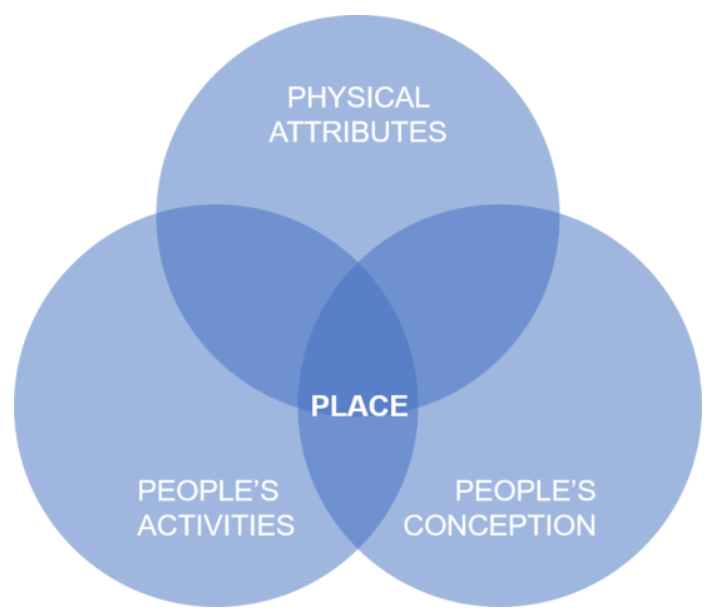

Fig. 2. Space conception diagram (Source: David Canter 'The Psychology of Place' (1977: p. 158), redrawn by authors)

One important distinction need to be made between 'space' and 'place'. When a meaning, which is consisted of activities and user's conception, is inserted on a 'space', it then transforms into a 'place'. In a simple way, a 'place' is formed when three required elements (space, user, and time) meet. In this contexts, those three elements are very dynamics and complementary. Hence, the understanding of a 'space' can be done under three lenses: first space (perceived), second space (conceived), and third space (lived) (Soja, 1996).

As stated previously, the recent global trend has been pushing architectural work to be more sustainable, therefore, it requires a redefinition of 'space'. A sustainable architectural work is an architectural work that is able to feed both the current and future needs of a society. A sustainable architecture covers three aspects: environment, social, and economy (Steele, 1997). Specifically, sustainability is shaped and influenced by its natural resources, local society, and the efficiency of operational cost.

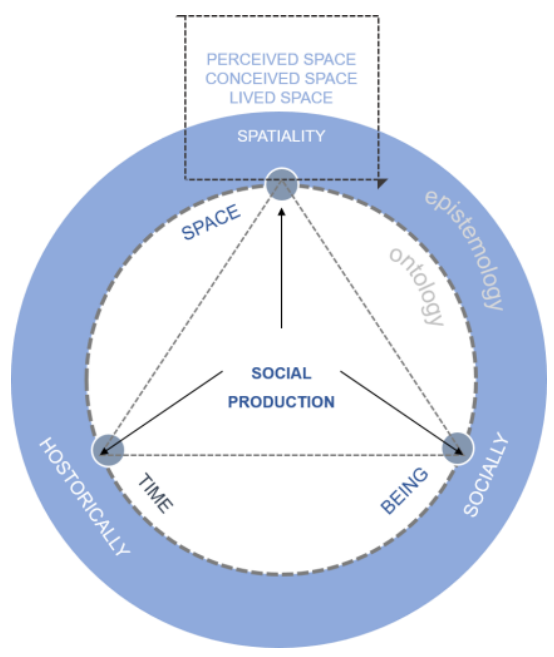

Fig. 3. Space as the result of social construction

In practice, to achieve a sustainability, an architectural work needs to incorporate those three elements. It needs pay attention to efficiency of energy, material, and land. It needs to be aware of the latest technology and the waste management control. This is the green design. The design that emphasize the temporality of space, time, and user, which are embed in its adaptability and flexibility. A green design will produce efficiency in facilitating more than just one function of a space. This is the face of the future sustainable architecture.

\section{FINDINGS AND DISCUSSION}

\section{Findings}

The findings presented on this section are various architectural works as the case studies for the basic model constructed previously. There are a total of nine case studies presented, three case studies based on secondary data source (literature study) and six based on primary data source (field observation). These nine cases studies are being classified further into three types of temporality (space, user, and time).

GROUP I. Case studies based on secondary data are:

1. Information center in Spain - Space Temporality

2. Tirana cultural center in Albania - Time Temporality

3. Kyoto capsule hotel in Japan - User temporality 
GROUP II. Case studies based on primary data collected in Surabaya are:

1. Arhitecture Studio of Petra Christian University and Public Plaza of Petra Christian University Space Temporality

2. Kita Kita Food Studio and Street Market at Tropodo-Time Temporality

3. Intro Café and Plaza Tunjungan Atrium - User Temporality

\section{GROUP ONE: SECONDARY DATA CASE STUDIES}

\section{Information Center in Spain}

This information center located in Spain. It is designed by Peris+Toral Architect. The smart design of this facility uses scaffolding system. The temporality of space in this facility is apparent of the flexibility of transformation of its room configuretions. This flexibility of transformation thus provides various different space functions that can be served by its rooms, such as art gallery, information pavilion, bicycle-park, and some other needed room functions.

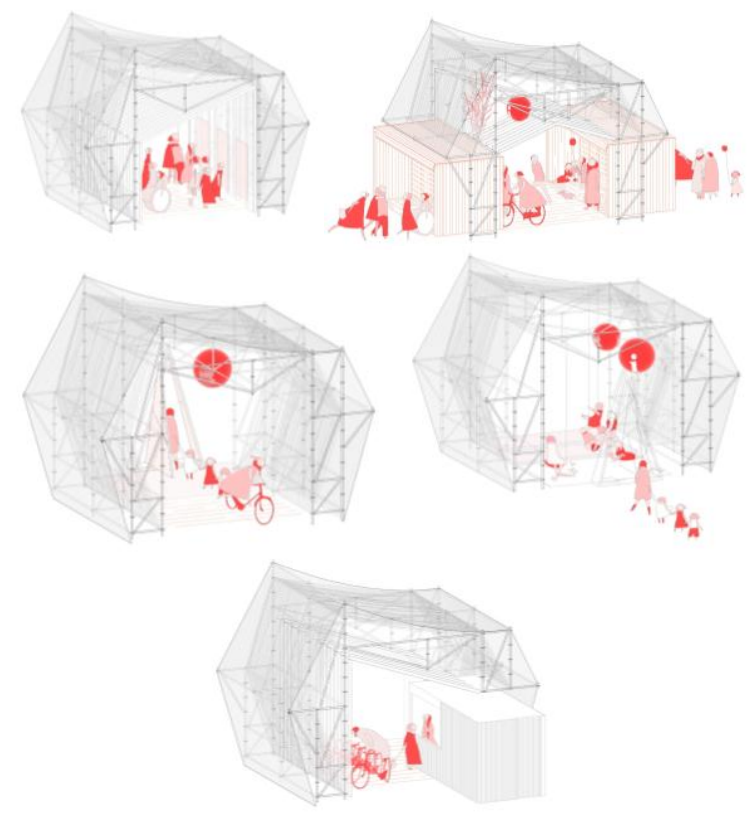

Fig. 4. Space temporality in Spain information center (Source: Peris+Toral Architect's Project, 2015)

\section{Culture Center in Albania}

The second facility is a cultural center located in Tirana, Albania. It is designed by Bjarke Ingels Group. It is inspired by the Axial of Albania city. The architect designs the facility with the intention to provide a public plaza which can also accommodate the need of the Moslem people for a space to pray during their praying time. This shows how one space provides two different functions in different times.

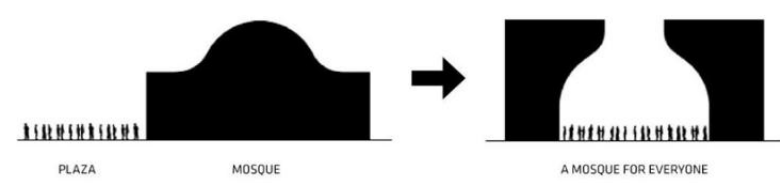

Figure 5. Time temporality in Albania culture center (Source: Bjarke Ingels Group's Project, 2011)

\section{Kyoto Capsule Hotel in Japan}

The third well known architectural work is a modular hotel located in Kyoto, Japan. This is a work of Fumie Shibata design studio. In one period of time, the same configuration of space serves different variety of user. While the main function of this rented space is for resting in a modular space for approximately nine hours, this hotel can also highlight the existence of temporality of user.

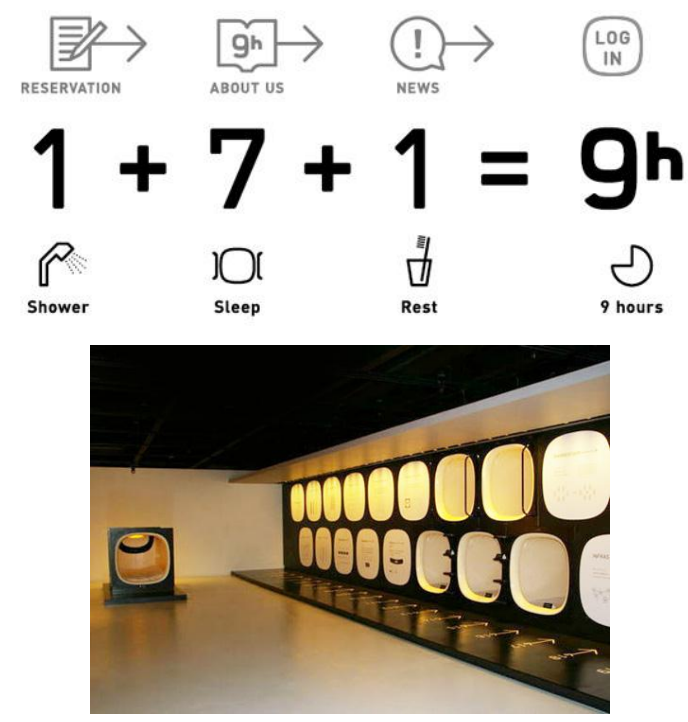

Fig. 6. User temporality in Kyoto capsule hotel (Source: Fumie Shibata's Project, 2009)

\section{GROUP TWO: PRIMARY DATA CASE STUDIES}

\section{Architecture Studio in Petra Christian University}

One of the examples for the temporality of space is the academic studio located at the Petra Christian University, Surabaya. It is a studio provided to accommodate the curriculum requirement of the architecture students with a basic room setting (certain table and chair position) required for academic purpose. However, this basic setting can be changed based on other activities' requirements, such as worship activities, a gallery system configuration, or a simply change of furniture setting into a radial centered space. Despite of this changing of room setting ability, the user has to remain the same (the architecture student). 


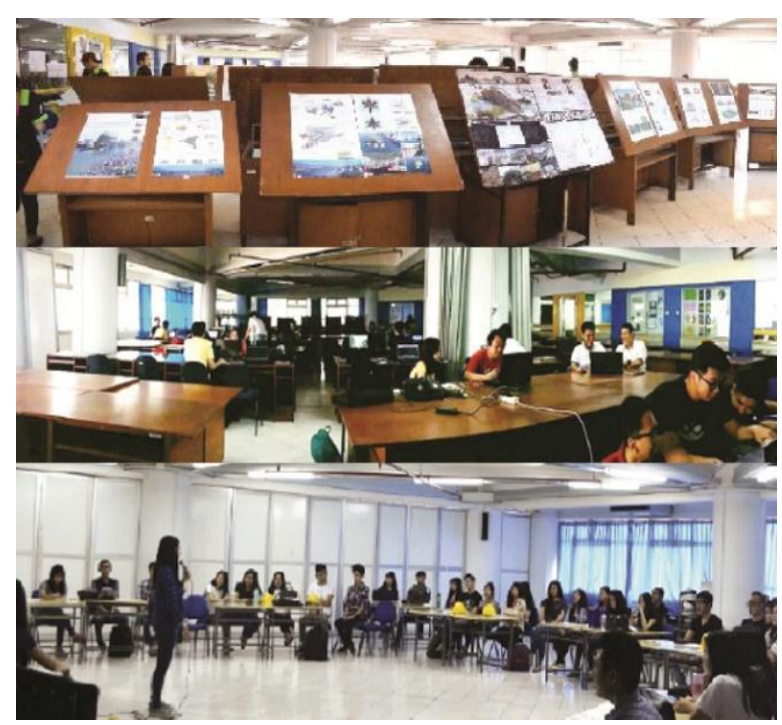

Fig. 7. Space temporality in architecture studio

\section{Public Plaza of W Building at PCU}

Another area located in Petra Christian University that provide case of temporality of space is the Public Plaza. It is located in one of the university buildings. The function of this plaza changes in different period of time. With its dynamic configuretion, other than a hangout space for students during their free time, this plaza can be used for various nonformal student activities and also various other public activities held by the university, such as gallery or showcase area.
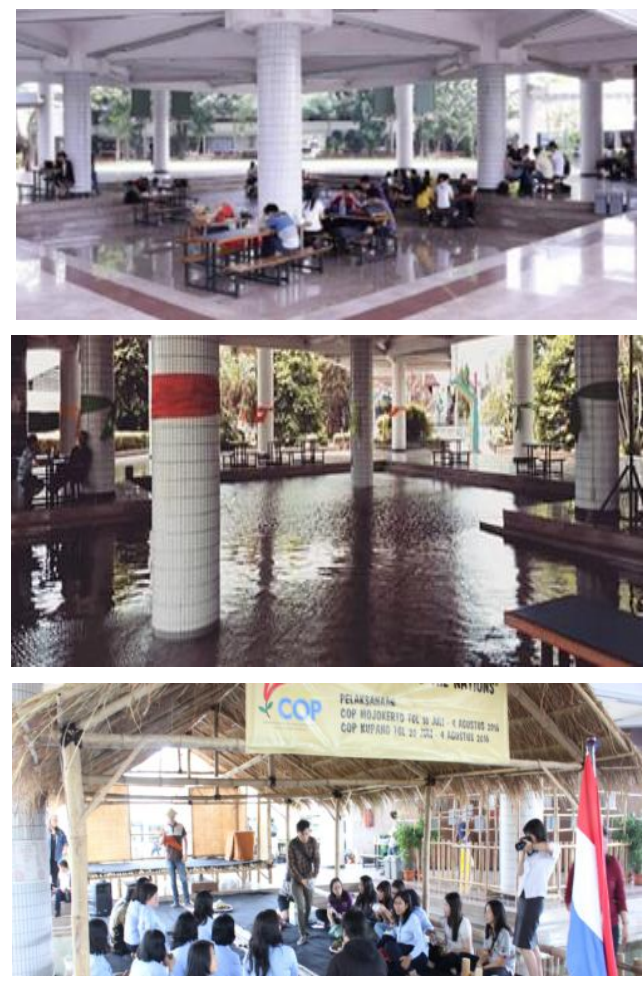

Fig. 8. Space temporality in public sunken plaza

\section{Kita-Kita Food Studio}

The first case for the temporality of time based on the primary data is a café called "Kita-Kita Food Studio", which is located in Jemursari street, Surabaya. This café is more of a food studio designed to accommodate different types of activity in different period of time of a day. Throughout the morningnoon, it functions as a rented space for meeting, workshop, and similar type of activities. The café operated in the afternoon-night time. As a café, it serves food and beverages and this activity does not occur in the morning-noon time. Due to these two different purposes, the setting of its furniture is flexible and can be easily transformed to serve the temporality of time.

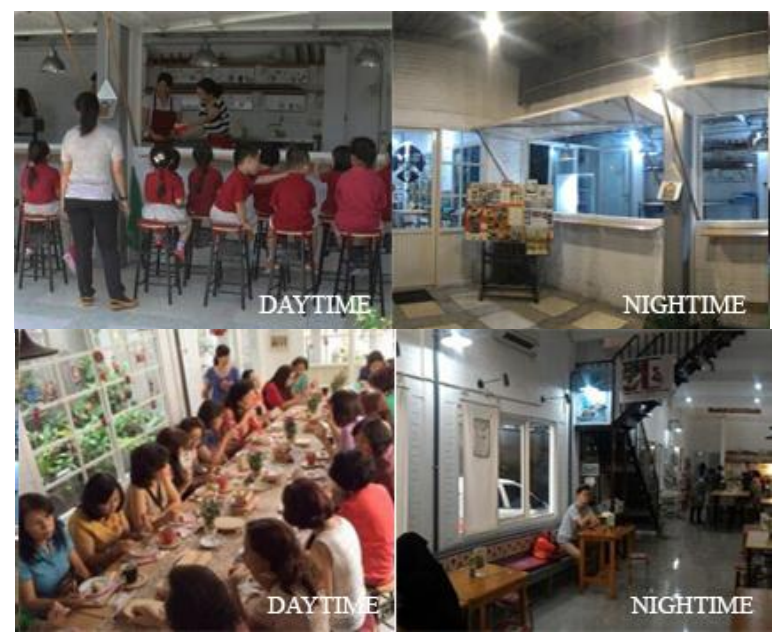

Fig. 9. Time temporality in kita kita food studio

\section{Tropodo Morning Market}

Another case for a temporality of time is a temporary market with the morning market at Tropodo area as an example. This is very common in various housing areas in Indonesia. This type of market occurs when a sudden activity of traditional market often 'being established' at one of an empty corner or empty road in a rigid housing are configuration. This activity occurs daily but only in the morning with most of its trace gone in the afternoon. This type of activity shows that certain public activities can be occurred in a space that is not specially intended for that certain type of activities.
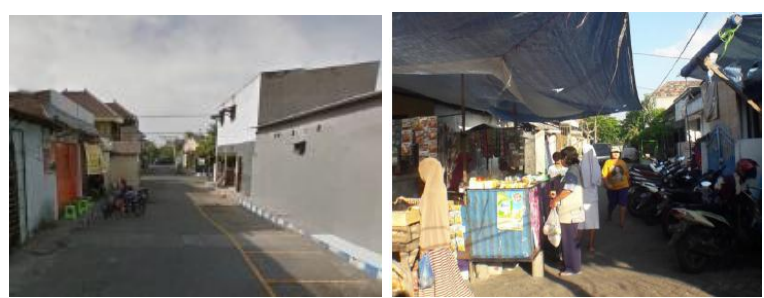

Fig. 10. Time temporality in morning market of Tropodo 


\section{Intro Cafe}

One of the case for the temporality of user is a café called "Intro Café" located in Surabaya. The uniqueness of this café is on its concept that always changes every 2-3 months, following a magazine content. The renters/sellers are users who are able to personalize the room space and create their own branding. Again this is an example of a temporality of user.
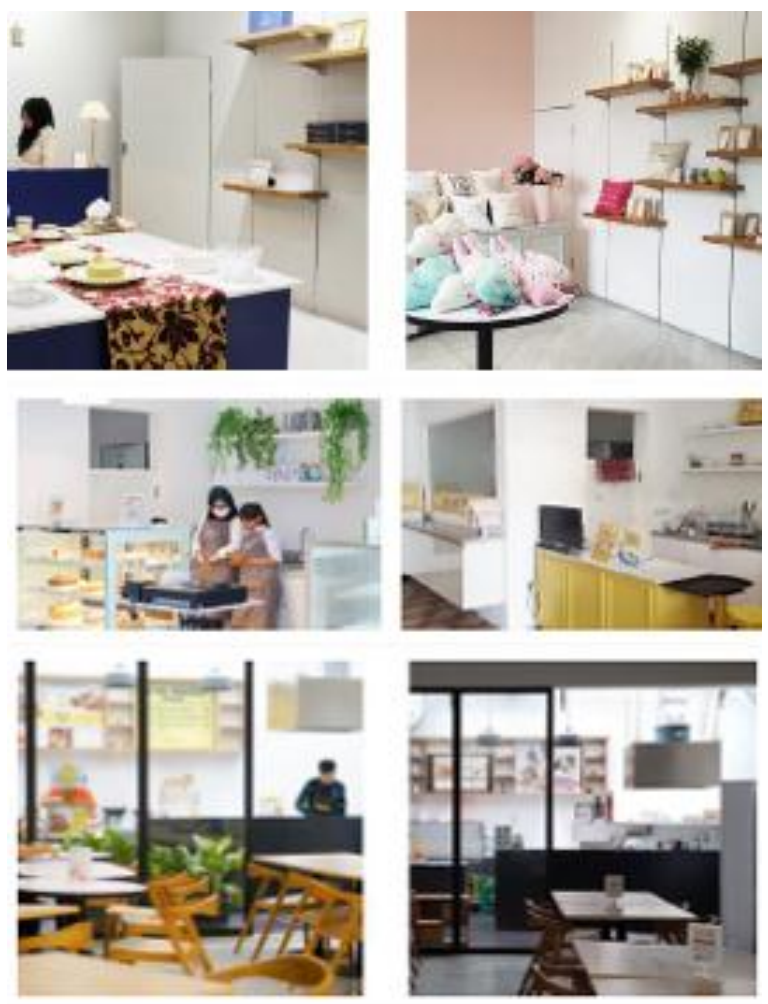

Fig. 11. User temporality in Intro Café

\section{Plaza Tunjungan's Atrium}

Another case for temporality of user is the central atrium of Tunjungan Plaza III (shopping mall), Surabaya. This is a multipurpose hall that can be transformed based on variety of activities. It is located in the middle of a shopping mall and can serves for various occasions, such as worship event, sports, exhibition, etc. The flexibility and adaptability of its oval shaped layout are designed for a temporary type of activity that can only lasted for short period of time.

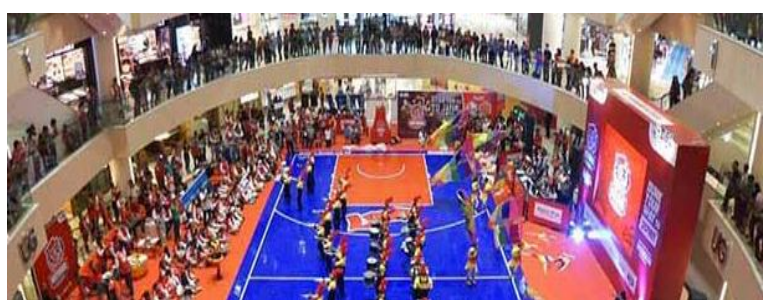

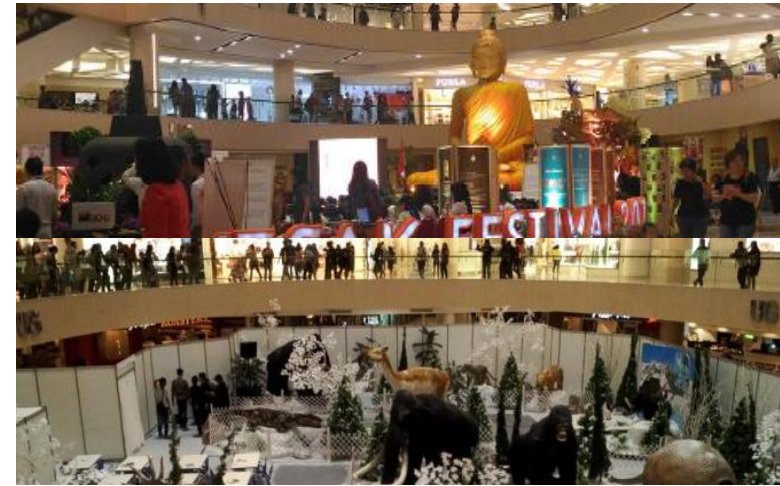

Fig. 12. User temporality in Mall Atrium

\section{Summary of Findings}

All of the nine case studies presented above show three types of temporality. It provides examples of temporality of space, user, and time in different parts of the world that occurs in different period of times and involving different societies. While the nine case might show different degree of temporality, they are still show that these three types of temporality has been existing all along:

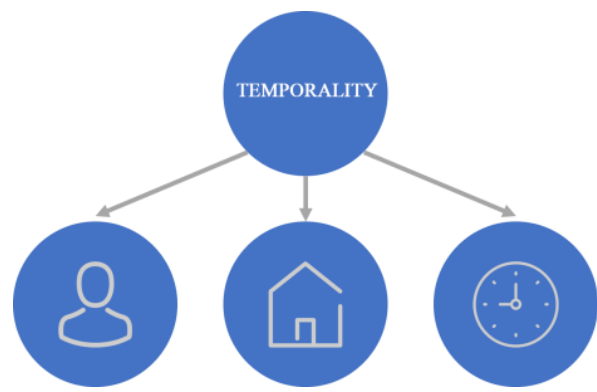

Fig. 13. Classification of temporality

Temporality of space occurs when there is a flexibility of space configuration to accommodate the various different types of activity. A space can be transformed based on its usages. However, there is a limited room for user variety and the user tend to be homogenous.

Temporality of time occurs when there are two different types of activities that occur in one space in two different time. The period of the activity tends to be short.

Temporality of user occurs when there are various types of user doing their activities in the same area for a long period of time. This type of temporality can be often found at a rented space with a flexible and adaptive room setting based on the need of the user for certain period of time.

In sum, by applying the basic conceptual model from the literature review to the nine cases (both secondary data and primary data), here are some of 
the characteristics that can be found for the three type of temporality.

Temporality of Space:

- The space can be mobile or transformative

- Adaptive and flexible with various different scenarios and configurations

- Multi-activities exist in one space (with incorporation of transformable room setting)

- The type of user tends to be homogenous

- Some of them use technology to support the transformative form

- Semi private usage, not public

- The answer of city density problem (due to limited land)

Temporality of User:

- Rentable space for certain period of time

- Modularity with the same configuration, in large number

- The activities tend to be similar (despite the existence of several variants)

- Static, not mobile

- Public user with private activities (resting area, office space, etc)

- The answer to limited land

- Similar user in large number in the same period of time

Temporality of Time:

- Occurs in public space of the city (involving group activities)

- User type is variative

- Static space

- Collective activities in large number

- Eventually, occurs in certain period of time (short time)

- Flexible amount of user

- Public access

- Can be negative while unplanned

- Limited time activities

As an architect, who bear the responsibility of designing a building, these temporalities needs to be addressed, anticipated, and used as an advantage to provoke creative new designs in different types of building. Some of the building or establishment examples that can be exploited from its temporality nature, are:

- Temporality of Space: apartment unit, rental office space, design studio, pavilion, café, etc.

- Temporality of User: hotel, apartment, boarding house, multipurpose hall, etc.

- Temporality of Time: street market, public plaza, alun alun, city park, etc.

\section{Discussion: Temporality in the Sustainable Architecture}

The incorporation of these three temporalities into a designing process is one of the keys to answer the challenges of promoting a sustainable architecture as it will lead to an efficient land usage. A change of perspective needs to be made when it comes to designing a room based on functions. From a room that can only serve one function into a room with a degree of adaptability and transformability to serve various different functions. Several different functions can be incorporated by: 1) a simple change in a room configuration (temporality of space); 2) maximization and effective use of time (temporality of time); and 3) taking advantage from different types of user (temporality of user).

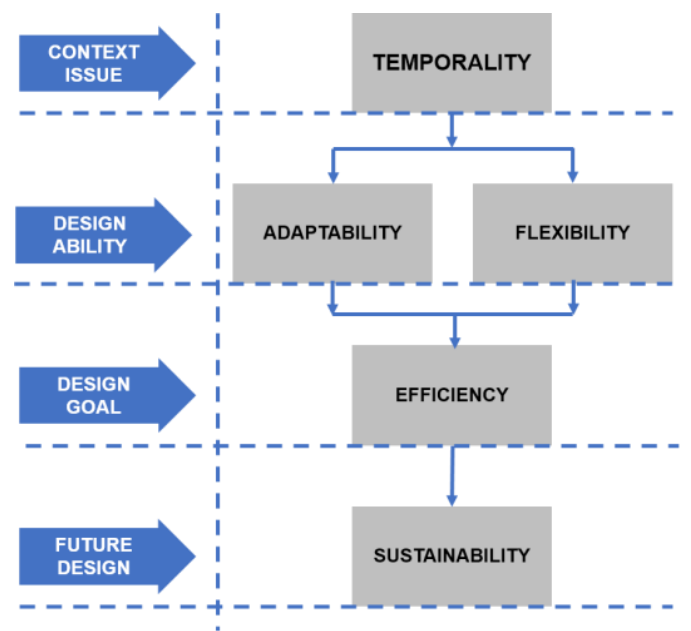

Fig. 14. The relation between temporality and sustainability

Table 1. Characteristic of Temporality

\begin{tabular}{|c|c|c|c|}
\hline & $\begin{array}{l}\text { Temporality in } \\
\text { Space }\end{array}$ & $\begin{array}{c}\text { Temporality in } \\
\text { User }\end{array}$ & $\begin{array}{l}\text { Temporality in } \\
\text { Time }\end{array}$ \\
\hline Facility & Private/Semi & Public & Public \\
\hline Category & Public & & \\
\hline User Type & Homogenic & Heterogeneous & Heterogeneous \\
\hline Physical Space & Dynamic & Static & Static \\
\hline Ownership & Private & Rentable & Rentable \\
\hline User Number & Limited & Limited & Unlimited \\
\hline Characteristic & $\begin{array}{l}\text { Modularity - } \\
\text { High } \\
\text { Technology }\end{array}$ & Multipurpose & $\begin{array}{l}\text { Public/Open } \\
\text { Space }\end{array}$ \\
\hline Location & $\begin{array}{l}\text { Permanent, } \\
\text { Mobile }\end{array}$ & Permanent & Permanent \\
\hline $\begin{array}{l}\text { Usage period } \\
\text { of time }\end{array}$ & $\begin{array}{l}\text { Short period, } \\
\text { keep changing }\end{array}$ & $\begin{array}{l}\text { Certain longer } \\
\text { period of time }\end{array}$ & $\begin{array}{l}\text { Short period, } \\
\text { keep changing }\end{array}$ \\
\hline
\end{tabular}

\section{DISSCUSSION}

In most cases, in the architectural world, the presence of temporality tends to be neglected both by the designer (architect) and the user (society). There 
are many of activities that occur only for a certain period of time and can easily stopped or changed drastically. However, based on the existing studies, lately there are various international architects who have been acknowledging it and, therefore, incorporate temporality into their design. Thus, their designs do not only solve certain architectural issues presented by various limitations, their designs also become a breakthrough in the sustainable architectural world. This particularly true in the case of land usage limitation as one of the major problems in big cities or cities with a high-density population.

Based on the empirical findings of this research, sustainability consideration in terms of flexibility and adaptability are planned and unplanned design. Architects in this case study, applied flexibility mostly in regard to space and cost efficiency to face the challenge of a dynamic lifestyle of the society (for example the Tunjungan Plaza Atrium and Intro Café). On the other hand, the Tropodo morning market has shown the unplanned condition that it informally occupies specific neighborhood streets but accepted by the society. The arrangement of adaptabilityflexibility of space requires other aspects of 'space' (theoretically) to be also dynamic, which are time and society. The three aspects of space as a social production have their own degree of dynamic/change; or in other words, when the focus of temporality is in space (as the focus of most architects), the users and time-usage should be in a dynamic situation.

The degree of temporality in three different types (space, user, time) might differ from one case to another, but this does not reduce its importance and shall be used to provoke certainty; a creativity that comes from the effort to create a preventive design. A design that combines all of possibilities and potentials of a place that originally can only serve one single functions. This logic works for a small room to a bigger scale such as city. No matter the size, all of the architectural works cannot neglect temporality.

A discussion of sustainability in architectural world does not only relate to physical limitations, such as energy efficiency, material choice. The core of a sustainable architecture lies on its adaptability and flexibility. To achieve a sustainable architecture, it takes more than just a small scale of discussion of architectural concepts; it takes a massive awareness and a global re-definition of architecture to challenge the old perspective and to create a better sustainable design.

\section{ACKNOWLEDGEMENT}

This article was based on a field observation carried out in Surabaya in 2017, as part of Temporality-Adaptability Architecture an elective course. It was sponsored by the Department of Architecture, Petra Christian University, Surabaya. The students who involved in this work are: Gabriella Rosely, Nugraha Adhi, Alvanita Mahagol, Siska Hadiwijaya (Team-1); Kannigia Liang, Melinda Sulistiani, Ishak Tedjowidjojo, Natasha Hariyono (Team-2); Angela, Ayling Azalia, Jonathan Supranata, Karl Matthew (Team-3).

\section{REFERENCES}

Canter, D. (1977). The Psychology of Place. London: The Architectural Press Ltd.

Damayanti, R. (2015). Extending Kevin Lynch's Theory of Imageability; through an investigation of kampungs in Surabaya- Indonesia. The University of Sheffield, Sheffield UK. Retrieved from http://etheses.whiterose.ac.uk/view/creators/Damayanti=3ARully=3A=3A.html

Lefebvre, H. (1991). The Production of Space. Victoria: Blackwell Publishing.

Soja, E. W. (1996). Thirdspace; Journeys to Los Angeles and Other Real-and-Imagined Places. Oxford: Blackwell Publisher.

Steerle, J. (1997). Sustainable Architecture: Principles, Paradigms, and Case Studies. London: Mcgraw-Hill

Tuan, Y. F. (1977). Space and Place: The Perspective and Experience. London: Edward Arnold.

Archdaily. (2016, 05 October). A Scaffolding System for a Temporary Facility. Accessed 20 July 2017, from http://www.archdaily.com/796646/ascaffolding-system-for-a-temporary-facilityperis-plus-torarquitectes

Archdaily. (2011, 04 May). BIG Wins The Competition To Design A Major Cultural Center In Albania. Accessed 20 July 2017, from http://www.archdaily.com/132808/big-wins-thecompetition-to-design-a-major-cultural-centerin-albania

Designboom. (2009, 10 Nov). Fumie Shibata's '9 H (Nine Hours)' Capsule Hotel In Kyoto. Accessed 20 July 2017, from http://www.designboom. com/architecture/9-h-nine-hours-capsule-hotelin-kyoto/ 